\title{
Canopy and Litter Cover do not Alter Diaspore Removal by Ants in the Cerrado
}

\author{
MA RABELO ${ }^{1}$, MA ANGOTTI ${ }^{2,3}$, GS SILVA ${ }^{1}$, AC REIS ${ }^{1}$, CR RIBAS ${ }^{2}$ \\ 1 - Universidade Federal de Lavras, Programa de Pós-Graduação em Ecologia Aplicada, Departamento de Biologia, Lavras-MG, Brazil \\ 2 - Universidade Federal de Lavras, Laboratório de Ecologia de Formigas, Departamento de Biologia, Lavras-MG, Brazil \\ 3 - Instituto Federal de Educação, Ciência e Tecnologia de Mato Grosso do Sul - Campus Ponta Porã, Ponta Porã, Mato Grosso do Sul, Brazil.
}

\section{Article History \\ Edited by \\ Kleber Del-Claro, UFU, Brazil

Received 22 July 2020 \\ Initial acceptance 14 September 2020 \\ Final acceptance 09 November 2020 \\ Publication date 28 December 2020}

\section{Keywords}

Temperature, humidity, vegetation cover, diaspore removal, myrmecochory, conservation.

\section{Corresponding author}

Mariana Azevedo Rabelo

iD https://orcid.org/0000-0003-1425-0337

PPG em Ecologia Aplicada, Setor de

Ecologia e Conservação, Laboratório de

Ecologia de Formigas, Instituto de Ciências

Naturais, Departamento de Biologia,

Universidade Federal de Lavras

PO Box 3037, CEP 37200-900,

Lavras, Minas Gerais, Brasil.

E-Mail: rabeloama@gmail.com

\begin{abstract}
Diaspore removal by ants is a crucial stage for successful myrmecochory and can be directly or indirectly affected by natural or anthropic changes to environments. Among the consequences of such changes is variation in habitat attributes, such as changes in conditions and resources and, consequently, decreased diaspore removal or even the loss of this ecological process. The aim of this study was to assess whether canopy and litter cover affect diaspore removal by ants in the Cerrado. We considered canopy and litter cover as proxies of humidity and temperature and evaluated whether changes in these environmental conditions could affect diaspore removal by ants. We hypothesized that the greater the canopy and litter cover (higher humidity and lower temperature), the smaller the number of diaspores removed by ants, since Cerrado is an open environment. We tested this hypothesis by establishing three classes of cover for each proxy: low, intermediate, and high. We placed artificial diaspores under each cover class and quantified the number of diaspores removed. We found that variation in canopy and litter cover did not affect the number of diaspores removed by ants in studied areas of Cerrado sensu stricto. We suggest that variation in habitat attributes in natural environments were less important for diaspore removal than in modified areas. Our results indicate that understanding the processes and habitat attributes involved in diaspore removal by ants is important for conserving the Cerrado.
\end{abstract}

\section{Introduction}

Increased habitat fragmentation and habitat loss, and the consequent decline in species richness, due to anthropogenic activities can have direct and indirect effects on ecological processes, such as diaspore removal by ants (myrmecochory) (Christianini et al., 2007; Bieber et al., 2014). Highlighted among the direct effects are changes in the composition of ant assemblages, which could involve a decrease or loss of highquality diaspore removing species and increased removal by generalist species, with a negative effect on removal success (Zelikova \& Breed, 2008; Leal et al., 2014). However, there are cases where anthropogenic disorders can be related to variance in the general composition of dispersing ants, but not to their abundance and to the service provided by high-quality removers (Oliveira et al., 2019).

Among indirect effects, decreased diaspore dispersion can affect the distribution and structure of vegetation (Del Toro \& Ribbons, 2019), and contribute to diaspore predation by other species (Santana et al., 2013). For ants, the main indirect effects of habitat disturbance are associated with effects on habitat structure, microclimate, resource availability and competitive interactions (Andersen, 2018). Therefore, environmental alterations initiate changes in ecological dynamics and interactions among species and between species and their environment (Oliver et al., 2016). Ants assume an 
important role in diaspore dispersion since they act not only as primary dispersers, but also as secondary dispersers for nonmyrmecochorous diaspores (Anjos et al., 2020). The removal of diaspores is possibly one of the most important steps in the dispersion process, as the type of interaction can be crucial for the viability, germination and establishment of the seedling (Gallego et al., 2014; Magalhães et al., 2018). Most research on myrmecochory, either in natural or modified habitats, has identified factors that explain dispersal distance (Andersen \& Morrison, 1998; Gómez \& Espadaler, 2013), and size, quality, and quantity of removed diaspores (Leal et al., 2014). However, little has been discussed about how environmental conditions, that are linked to environmental variation, can influence the process of diaspore dispersion (Warren et al., 2012; Del Toro \& Ribbons, 2019).

Finding and removing diaspores is crucial for successful myrmecochory and so it is important that the ant assemblage of a given area is capable of performing this ecological process. At a local scale, however, habitat heterogeneity and complexity may influence ant species richness. Ant species richness responds to microclimatic factors (Kaspari et al., 2004; Weiser et al., 2010), with temperature being one of the most relevant to the distribution of species, and they can influence foraging behaviors related to the physiological tolerances of species (Fitzpatrick et al., 2014). Changes in habitat complexity, such as variation in vegetation structure (Gibb \& Parr, 2010), canopy and litter cover and tree density, affect the richness and composition of ant assemblages (Neves et al., 2013). Increased canopy cover decreases the incidence of sunlight and, consequently, alters the microclimate, which influences the availability, quality, and quantity of resources (Kaspari et al., 2004). Shaded areas can provide more suitable conditions for arthropod communities due to a more stable microclimate and higher resource availability (Levings, 1982). However, myrmechocory can be favored in open and dry environments, and higher removal rates are expected in these environments where this interaction has coevolved more often (Lengyel et al., 2009; Lengyel et al., 2010).

Ants are considered the main removers of nonmyrmecochorous diaspores and a great portion of ground-dwelling ant communities are involved in this process (Pizo \& Oliveira, 2001; Passos \& Oliveira, 2003). Changes in the amount of litter cover, the main component of the epigeic stratum (Yanoviak \& Kaspari, 2000), can affect the diversity and distribution of ground dwelling ants (Cardoso \& Schoereder, 2014). Such changes in litter cover can also affect microclimatic conditions, such as temperature, humidity, and solar incidence (Ahuatzin et al., 2019). The rate of diaspore removal by ants can be $10 \%$ higher in Cerrado areas than in cultivated areas (Rocha-Ortega et al., 2017), which reinforces the importance of this biome in the maintenance of ecological processes (Rabello et al., 2018).

How changes in habitat heterogeneity and complexity affect diversity of ant assemblages is well described in the literature (Palfi et al., 2017; Queiroz et al., 2017). Nevertheless, how habitat heterogeneity and complexity affect the ecological functions performed by ants, especially the removal and dispersion of diaspores, is not yet clear. Consequently, the relationships among temperature, humidity and diaspore removal are not well explored. Considering that environmental anthropization can change vegetation cover and microclimatic conditions, it is likely that such environmental changes could also negatively affect the ecological process of diaspore removal by ants.

In this context, the aim of our work was to evaluate whether changes in environmental conditions related to humidity and temperature (estimated by canopy and litter cover) could affect diaspore removal by ants in natural habitats. We hypothesized that the greater the canopy and litter cover, the smaller the number of diaspores removed by ants, since Cerrado is an open environment.

\section{Methods}

Study Area

The study was carried out on March 2016 in an area of cerrado sensu stricto ( $\left.15^{\circ} 26^{\prime} 00^{\prime \prime} \mathrm{S}, 44^{\circ} 49^{\prime} 19^{\prime \prime} \mathrm{W}\right)$, characterized by heterogeneous habitats, composed of herbaceous, grasses, shrubs and scattered trees that provide different vegetation structures (Oliveira-Filho \& Ratter, 2002). The area is part of Área de Proteção Ambiental do Rio Pandeiros (APA Rio Pandeiros), municipality of Januária, northern Minas Gerais State, Brazil, considered the largest conservation unit in the state, with $396.060,407$ hectares. The climate of the area is semiarid with a mean annual temperature between 18.4 and $30.9^{\circ} \mathrm{C}$ and a mean annual precipitation of $903.0 \mathrm{~mm}$ (Jardim \& Moura, 2018). The region is under many environmental pressures involving anthropogenic activities, such as vegetation loss, fire, monocultures (eucalyptus), pasture, and charcoal production (Nunes et al., 2009).

\section{Canopy and Litter Measurements}

To determine whether the number of diaspores removed by ants is influenced by environmental conditions and resources, we considered canopy and litter cover as proxies for such environmental characteristics, temperature and humidity. Litter cover was measured as the percentage of covered soil (organic matter, twigs, sticks, leaves, and diaspores), considering only visual covering, and not measuring litter heterogeneity or volume. To do this we threw a $25 \times 25 \mathrm{~cm}$ wire quadrat, that was subdivided into four quadrants, onto the soil and estimated the percentage of covered soil in the quadrat (modified from Queiroz et al., 2013). We measured canopy cover by estimating the percentage of shaded quadrats using a concave forest densiometer (TerraGes). We established three classes of covering for each proxy to guarantee natural variation of measurements: 0 to $33 \%$ for low cover (LC), 34 to $66 \%$ for intermediate cover (IC), and 67 to $100 \%$ for high cover (HC). We then selected 15 sample points for each class, ensuring that they were 20 meters apart from each other, such that each independent variable, canopy and litter cover, had 45 sample points. 


\section{Diaspore Removal}

We placed 20 artificial diaspores at each sample point, which were plastic beads ( $0.03 \mathrm{~g}$ and $2 \mathrm{~mm}$ diameter) covered with an attractive paste (75\% hydrogenated vegetable fat, $7 \%$ casein, $5 \%$ flavorless maltodextrin, $4.8 \%$ fructose, $4.7 \%$ glucose, $3 \%$ calcium carbonate and $0.5 \%$ sucrose) (based on Raimundo et al., 2004; Bieber et al., 2014; Rabello et al., 2015). The diaspore's size allows both small and large ant species to perform diaspore removal (Pizo \& Oliveira, 2001; Leal et al., 2014; Anjos et al., 2020). In regard of the attractive portion of artificial diaspores, its composition is chemically similar to natural ones that are attractive to ants. Ants are attracted to diaspores with different proportions of lipids, either for myrmechocorous, or non-myrmechocorous diaspores (Pizo \& Oliveira, 2001; Leal et al., 2014).

We used artificial diaspores since we could not find any plant species with enough arillate diaspores (nonmyrmecochoric) to perform the study. Nonetheless, studies on diaspore removal and dispersion have shown that artificial diaspores are suitable alternatives for studies of myrmecochory (Bieber et al., 2014; Angotti et al., 2018), since they allow the replication of experiments and maintain the uniformity of physical and qualitative characteristics of diaspores.

We provided a total of 300 artificial diaspores for each sampled class (LC, IC, and HC). both for litter and canopy covers. The diaspores were made available from $07 \mathrm{~h} 00$ to $10 \mathrm{~h} 00$ am at sample points that were protected by wire mesh $(20 \mathrm{x}$ $20 \mathrm{~cm}, 1.5 \mathrm{~cm}$ mesh) to avoid removal or predation by other invertebrates and vertebrates (Pizo \& Oliveira, 2001; Rabello et al., 2015; Angotti et al., 2018). We quantified the number of diaspores at each point at the end of the exposure time to calculate the quantity removed by ants for each cover class.

\section{Statistical Analyses}

We built generalized linear models (GLM's), with quasibinomial error distribution, for each variable (canopy and litter cover) separately to evaluate the proportion of diaspores removed by ants in the three established classes cover ( $(\mathrm{LC}$, IC, and HC) (Crawley, 2013). The proportion of removed diaspores (dependent variable) was related to canopy and litter cover (independent variables) in two independent models. We performed a residual analysis to verify the distribution and fit of the models, considering a significance probability of $p$ $<0.05$ for all analyses. All analyses were performed with $\mathrm{R}$ software (R Development Core Team 2015).

\section{Results}

Of the 300 artificial diaspores provided for each canopy cover class, 253 diaspores were removed for LC, 278 for IC, and 231 for HC. Of the 300 provided for each litter cover class, 246 were removed for LC, 243 for IC, and 228 for HC (Table 1).

However, the proportion of diaspores removed by ants

Table 1. Variation in the removal of diaspores by ants by classes of canopy and litter cover: 0 to $33 \%$ (LC), 34 to $66 \%$ (IC) and 67 to $100 \%$ (HC) in Cerrado Stricto Sensu areas.

\begin{tabular}{lccc}
\hline Classes of covering & \% Seeds removed & Mean & SD \\
\hline Canopy cover & & & \\
Low cover (LC) & 84.33 & 16.86 & 5.65 \\
Intermediate cover (IC) & 92.67 & 18.53 & 4.24 \\
High cover (HC) & 77 & 15.40 & 0 \\
Litter cover & & & \\
Low cover (LC) & 81.66 & 15.20 & 4.94 \\
Intermediate cover (IC) & 81 & 16.20 & 0 \\
High cover (HC) & 76 & 16.40 & 2.82 \\
\hline
\end{tabular}

was neither affected by canopy cover $(\mathrm{F}=1.2 ; \mathrm{df}=42 ; \mathrm{p}=0.3)$ (Fig 1A) nor litter cover $(\mathrm{F}=0.1 ; \mathrm{df}=42 ; \mathrm{p}=0.9)$ (Fig 1B). Thus, our hypothesis, that areas with greater canopy cover (proxy for temperature and humidity) and greater litter cover (proxy for temperature, humidity, and resources) would have smaller diaspore removal, was rejected.
A

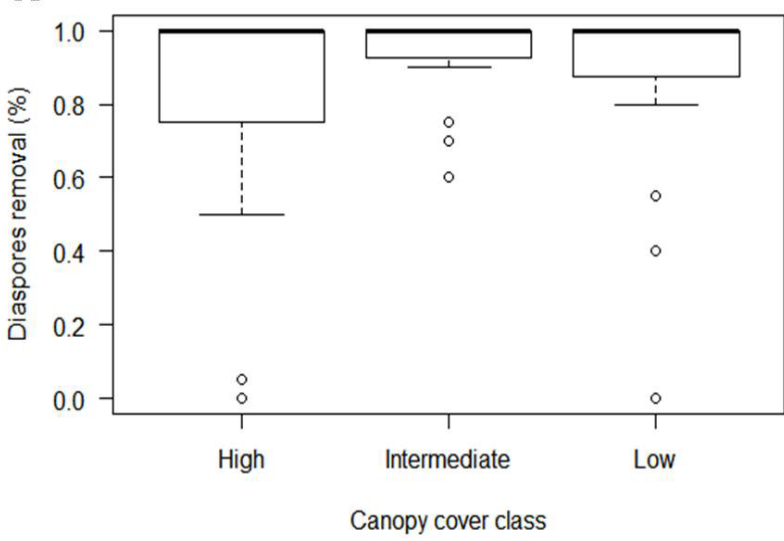

B

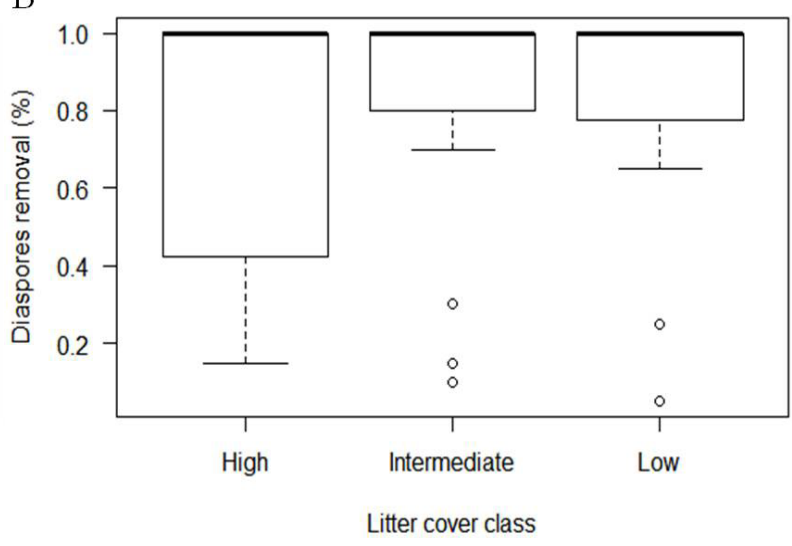

Fig 1. Proportion of artificial diaspores removed by ants under different (A) canopy cover class and (B) litter cover class in cerrado areas. 


\section{Discussion}

Among the many changes that can occur with environmental conditions, we investigated those related to how canopy and litter cover affect the removal of nonmyrmecocoric diaspores by ants in natural areas of Cerrado. We found both canopy and litter cover to have no effect on diaspore removal, which differed from our predictions.

At first, our results show that the percentage of canopy and litter cover does not interfere quantitatively in the removal of diaspores. This reinforces the importance of ants as one of the main secondary removers of diaspores in the Cerrado soil (Christianini et al., 2012; Magalhães et al., 2018). However, we cannot affirm that variations in canopy and litter cover, considered here as a proxy for temperature, humidity and resource, interfere in the quality of this process, as we do not collect the ants that performed the removals to find out if there is variation in the composition and the quality of the removing species.

Although we did not find an influence of the different coverages in the removal, the amount of diaspores removed was greater at the points where we evaluated canopy coverage than at the points evaluated for litter cover. What reinforces that ants possibly have different responses according to the environmental condition evaluated (Weiser et al., 2010). We observed that areas with higher and lower proportions of litter cover had similar diaspore removal. This finding contradicts our prediction since variation in litter cover did not have an effect on the ability of ants to find and remove diaspores in our study.

Assessments of the seed dispersal process in natural and post-disturbance environments point to an increase in the rate of removal by ants in more open environments (Andersen \& Morrison, 1998; Batisda \& Tavalera, 2002), with the impacts on the ant community being greater in these environments than indoors (Andersen, 2018). The rate of removal of diaspores and the composition of species of removing ants in savanna environments varies between open and closed areas (Andersen \& Morrison, 1998), with different land uses (Rabello et al., 2018) and different phytophysiognomies (Gallegos et al., 2014; Magalhães et al., 2018). Unlike our study, these studies evaluate and compare the dispersion process between different phytophysiognomies or in environments that have suffered some type of disturbance, where the conditions of the habitat are markedly different and can compromise the service of diaspore removal (Leal et al., 2014). Habitats that have gone through changes in land use and, consequently, changes in their attributes, show negative effects on diaspore removal by ants, such as over a gradient of tree cover (Rabello et al., 2018). The conversion of native forests into pasture, planted forests, and agroecosystems is highlighted as one of the main causes for declines in ecological functions (Philpott \& Armbrecth, 2006; Rabello et al., 2018). But is important to point out that in natural open environments, like Cerrado, higher removal rates are expected in habitats with smaller canopy and litter cover.
An important factor to be considered is that the microclimate conditions provided by the different canopy and litter cover can be within the thermal tolerance range of the removing species. The effects of microclimate variation, such as rising temperatures, have different effects on the ant community and depend on the species' thermal tolerance (Roeder et al., 2018). It is worth mentioning that we evaluated (although indirectly) the removal in relation to variations in conditions that occur in the area along years, differently from microclimate variations that occur throughout the day. Possibly, if we followed the removal along the daily temperature variation, we could verify if there are effects on the rate of diaspores removal throughout the day (Beamount et al., 2009; Angotti et al., 2018), but this is not our intend in this study.

Biotic conditions and microclimate variations have daily and seasonal variation and can interfere with interactions between species and resources, with foraging activity directly related to temperature (Hemmings \& Andrew, 2017). Hemmings and Andrew (2017) found that the body temperature of the ants showed no difference when they were on the ground and a nearby trunk, but varied between summer and winter. This suggests to us that perhaps the seasonal temperature variation is more important to alter the seed removal activity than the microclimate variation in a natural environment and with the same phytophysiognomy, which would explain the lack of effect of canopy and litter cover in our results.

It is well studied that habitat heterogeneity is an important factor for the composition of ant assemblages (Neves et al., 2013), and in some cases habitat differences have greater influences on community composition than on species richness (Pacheco \& Vasconcelos, 2012). Therefore, studies on the composition of diaspore remover assemblages can indicate the quality of ant removers and their possible role in successful diaspore dispersion (Rabelo et al., submitted). The variation in the proportion of canopy opening can contribute to the variation in the composition of the ant community in the area and in the quality of the removing species (Leal et al., 2014).

The lack of influence of canopy and litter cover on the removal found in our study, may be related to the adaptation of ants to variations in local conditions and microclimate. As a mosaic of phytophysiognomies, and with continuous or discontinuous canopy cover (Ribeiro \& Walter, 1998), the Cerrado provides variation in soil shading and the amount of litter, as observed in our study. In addition, interactions between ants and diaspores are generally opportunistic, being carried out by a range of omnivorous, carnivorous and fungivorous species (Christianini et al., 2012). Thus, the interactions between the ants and the diaspores we offer may have been opportunistic and been performed by high-quality removing species (Leal, et al., 2014), such as Ectatomma edentatum (Roger, 1863), Ectatomma opaciventre (Roger, 1861) or Ectatomma brunneum (Smith, 1858), which have been collected in other studies in the same region (Rabelo et al., in submitted). Because these species are larger, more agile and forage alone, they are more capable of traveling through different substrates. For smaller species, 
such as Pheidole jelskii (Mayr, 1884) and Pheidole capillata (Emery, 1906) (Rabelo et al., in submitted), litter thickness usually acts as a barrier (leaves, sticks, and fruits), hindering the foraging activity of ants (Farji-Brener et al., 2004) and, thus, decreasing diaspore transport.

Therefore, we highlight the importance of conserving the integrity of natural environments so that a full understanding of their processes and habitat attributes involved with diaspore removal by ants can be obtained. We also suggest further investigations of the interactions between seasonal variance and microhabitats. Studies of natural habitats may help us to understand the success of ecological functions and to identify the habitat attributes that are most important for preserving in order to guarantee ecological functions in both natural and modified habitats.

\section{Acknowledgements}

We thank the employees at Área de Proteção Ambiental do Rio Pandeiros for their accommodation support during field work, and to members of Laboratório de Ecologia de Formigas for discussions and contributions to this work. We thanks to suggestions from two anonymous referress in the previous version. This study was funded by the project APQ03593-12 "Desenvolvimento de ferramenta para priorização de descomissionamento de Pequenas Centrais Hidrelétricas (PHC) no estado de Minas Gerais e estudo de caso para a PCH Pandeiros", which was a partnership between Fundação de Amparo à Pesquisa de Minas Gerais (FAPEMIG) and Companhia Energética de Minas Gerais S. A. (CEMIG). We were also funded by FAPEMIG CRA PPM 00243/14. To conclude this work, MAR was granted a scholarship by FAPEMIG and MAA, GSS, and ACR were granted scholarships by CAPES.

\section{Authors Contribution}

MAR, MAA, GSS, and CRR conceived the idea and experimental design. MAR, MAA, GSS and ACR carried out field work and data acquisition. MAR and MAA performed analyses and data interpretation. MAR wrote the manuscript with substantial contributions from all authors.

\section{References}

Ahuatzin, D.A., Corro, E.R., Jaimes, A.A., Feitosa, M.R., Ribeiro, M.C., Acosta, J.C.L., Coates, R. \& Dáttilo, W. (2019). Forest cover drives leaf litter ant diversity in primary rainforest remnants within human-modified tropical landscapes. Biodiversity and Conservation, 28: 1091-1107. doi: 10.1007/ s10531-019-01712-z

Andersen, A.N. (2018). Responses of ant communities to disturbance: Five principles for understanding the disturbance dynamics of a globally dominant faunal group. Journal of Animal Ecology, 88: 350-362. doi: 10.1111/1365-2656.12907
Andersen, A.N. \& Morrison, S.C. (1998). Myrmecochory in Australia's seasonal tropics: effects of disturbance on distance dispersal. Australian Journal of Ecology, 23: 483491. doi: 10.1111/j.1442-9993.1998.tb00756.x

Angotti, M.A., Rabello, A.M., Santiago, G.S. \& Ribas, C.R. (2018). Seed removal by ants in Brazilian savanna: optimizing fieldwork. Sociobiology, 65: 155-161. doi: 10.13102/sociobiology. v65i2.1938

Anjos, D.V., Leal, L.C., Jordano P. \& Del-Claro K. (2020). Ants as diaspore removers of non-myrmecochorous plants: a meta-analysis. Oikos, 00: 1-12, doi: 10.1111/oik.06940

Batisda, F. \& Talavera, S. (2002). Temporal and spatial patterns of seed dispersal in two Cistus species (Cistaceae). Annals of Botany, 89: 426-434. doi: 10.1093/aob/mcf065

Beaumont, K.P., Mackay, D.A., Whalen, M.A., (2009). Combining distances of ballistic and myrmecochorous seed dispersal in Adriana quadripartita (Euphorbiaceae). Acta Oecologica, 35, 429-436. doi: 10.1016/j.actao.2009.01.005.

Bieber, A.G.D., Silva, P.S.D., Sendoya, S.F. \& Oliveira, P.S. (2014). Assessing the impact of deforestation of the Atlantic Rainforest on ant-fruit interactions: A field experiment using synthetic fruits. Plos One, 9: 1-5. doi: 10.1371/journal.pone. 0090369.

Cardoso, D.C. \& Schoereder, J.H. (2014). Biotic and abiotic factors shaping ant (Hymenoptera: Formicidae) assemblages in brazilian coastal sand dunes: The case of Restinga in Santa Catarina. Florida Entomologist, 97: 1443-1450. doi: 10.1653/024.097.0419

Christianini, A.V., Mayhé-Nunes, A.J. \& Oliveira, P. S. (2012). Exploitation of fallen diaspores by ants: are there antplant partner choices? Biotropica 44: 360-367. doi:10.1111/ j.1744-7429.2011.00822.x

Christianini, A.V., Mayhé-Nunes, A.J. \& Oliveira, P.S. (2007). The role of ants in the removal of non-myrmecochorous diaspores and seed germination in a neotropical savanna. Journal of Tropical Ecology, 23: 343-351. doi: 10.1017/ S0266467407004087

Crawley, M.J., (2013). The R book. Wiley, Chichester. Del Toro, I. \& Ribbons, R.R. (2019). Variation in ant-mediated seed dispersal along elevation gradients. PeerJ, 7:e6686. doi: 10.7717/peerj.6686.

Del Toro, I. \& Ribbons, R.R. (2019). Variation in ant-mediated seed dispersal along elevation gradients. PeerJ, 7:e6686. doi: 10.7717/peerj.6686

Farji-Brener, A. G., Berrantes, G., Ruggiero, A. (2004). Environmental rugosity, body size and access to food: a test of the size-grain hypothesis in tropical litter ants. Oikos, 104: 165-171. doi: 10.1111/j.0030-1299.2004.12740.

Fitzpatrick, G., Lanan, M.C. \& Bronstein, J.L. (2014). Thermal tolerance affects mutualist attendance in an ant-plant protection 
mutualism. Oecologia, 176: 129138. doi: 10.1007/s00442-0143005-8

Gallegos, S.C., Hensen, I., Schleuning, M. (2014). Secondary dispersal by ants promotes forest regeneration after deforestation. Journal of Ecology, 102: 659-666. doi: 10.11 $11 / 1365-2745.12226$

Gibb, H. \& Parr, C.L. (2010). How does habitat complexity affect ant foraging success? A test using functional measures on three continents. Oecologia, 164: 1061-1073. doi: 10.1007/ s00442-010-1703-4

Gómez, C. \& Espadaler, X. (2013). An update of the world survey of myrmecochorous dispersal distances. Ecography, 36: 1193-1201. doi: 10.1111/j.1600-0587.2013.00289.x

Hemmings, Z. \& Andrew, N. R. (2018). Effects of microclimate and species identity on body temperature and thermal tolerance of ants (Hymenoptera: Formicidae). Austral Entomology. doi: 10.1111/aen.12215

Jardim, C.H. \& Moura, F.P. (2018). Variações dos totais de chuvas e temperatura do ar na bacia do rio pandeiros, norte do Estado de Minas Gerais - Brasil: Articulação com fatores de diferentes níveis escalares em área de transição climática de Cerrado para semiárido. Revista Brasileira de Climatologia, 172-189. doi: 10.5380/abclima.vli0.61013

Kaspari, M., Ward, P.S. \&Yuan, M. (2004). Energy gradients and the geographic distribution of local ant diversity. Oecologia, 140: 407-413. doi: 10.1007/s00442-004-1607-2

Leal, L.C., Andersen, N.A. \& Leal, I.R. (2014). Anthropogenic disturbance reduces seed dispersal services for myrmecochorous plants in the Brazilian Caatinga. Oecologia, 174: 173-181. doi: 10.1007/s00442-013-2740-6.

Lengyel, S., Gove, A.D., Latimer, A.M., Majer, J.D. \& Dunn, R.R. (2009). Ants sow the seeds of global diversification in flowering plants. PLoS ONE, 4: e5480. doi:10.1371/journal. pone. 0005480

Lengyel, S., Gove, A.D., Latimer, A.M., Majer, J.D., Dunn, R.R., (2010). Convergent evolution of seed dispersal by ants, and phylogeny and biogeography in flowering plants: A global survey. Perspectives in Plant Ecology, Evolution and Systematics, 12: 43-55. doi:10.1016/j.ppees.2009.08.001

Levings, S.C. \& Franks, N.R. (1982). Patterns of nested dispersion in a tropical ground ant community. Ecology, 63: 338-344. doi: 10.2307/1938951

Magalhães, V.B., Espiríto Santo, N.B., Salles, L.F.P., Soares Jr., H. \& Oliveira, P.S. (2018). Secondary seed dispersal by ants in Neotropical cerrado savanna: species-specific effects on seeds and seedlings of Siparuna guianensis (Siparunaceae). Ecological Entomology, 43: 665-674. doi: 10.1111/een.12640

Neves, F.S., Queiroz-Dantas, K.S., Rocha, W.D., Delabie, J.H.C. (2013). Ants of three adjacent habitats of a transition region between the Cerrado and Caatinga biomes: The effects of heterogeneity and variation in canopy cover. Neotropical Entomology, 42: 258-268. doi: 10.1007/s13744-013-0123-7

Nunes, Y.R.F., Azevedo, I.F.P., Neves, W.V., Veloso, M.D., Souza, R.A. \& Fernandes, G.W. (2009). Pandeiros: O Pantanal Mineiro. MG Biota, 2(2): 4-17.

Oliveira, F. M., Andersen, A. N., Arnan, X., Ribeiro-Neto, J. D., Arcoverde, G. B., \& Leal, I. R. (2019). Effects of increasing aridity and chronic anthropogenic disturbance on seed dispersal by ants in Brazilian Caatinga. Journal of Animal Ecology, 88: 870-880. doi: 10.1111/1365-2656.12979

Oliveira-Filho, A.T. \& Ratter, J.A. (2002). Vegetation physiognomies and the woody flora of the cerrado biome. The Cerrados of Brazil: Ecology and Natural History of a Neotropical Savanna (ed. by P. S.Oliveira and R. J. Marquis), pp. 91-120. Columbia University Press, New York, New York.

Oliver, I., Dorrough, J., Doherty, H. \& Andrew, N.R. (2016). Additive and synergistic effects of land cover, land use and climate on insect biodiversity. Landscape Ecology, 31: 24152431. doi: 10.1007/s10980-016-0411-9

Pacheco, R. \& Vasconcelos, H.L. (2012). Habitat diversity enhances ant diversity in a naturally heterogeneous Brazilian landscape. Biodiversity Conservation, 21: 797-809. doi: 10.1007/ s10531-011-0221-y

Palfi, Z., Spooner, P.G. \& Robinson, W. (2017). Seed dispersal distances by ants increase in response to anthropogenic disturbances in australian roadside environments. Frontiers in Ecology and Evolution, 5: 132. doi: 10.3389/fevo.2017.00132

Passos, L. \& Oliveira, O.S. (2003). Interactions between ants, fruits and seeds in a restinga forest in southeastern Brazil. Journal of Tropical Ecology, 19: 261-270. doi: 10.1017/S026 6467403003298

Philpott, S.M. \& Armbrecht, I. (2006). Biodiversity in tropical agroforests and the ecological role of ants and ant diversity in predatory function. Ecological Entomology, 31: 369. doi: 10.1111/j.1365-2311.2006.00793.x

Pizo, M.A. \& Oliveira, P.S. (2001). Size and lipid content of nonmyrmecochorous diaspores: Effects on the interaction with litter-foraging ants in the Atlantic rain forest of Brazil. Plant Ecology, 157: 37-52. doi: 10.1023/A:1013735305100

Queiroz, A.C.M., Ribas, C.R. \& França, F.M. (2013). Microhabitat Characteristics That Regulate Ant Richness Patterns: The Importance of Leaf Litter for Epigaeic Ants. Sociobiology, 60: 367-373. doi: 10.13102/sociobiology.v60i4.367-373

Queiroz, A.C.M., Rabello, A.M., Braga, D. L., Santiago, G.S., Zurlo, L.F., Philpott, S.M. \& Ribas, C.R. (2017). Cerrado vegetation types determine how land use impacts ant biodiversity. Biodiversity and Conservation, 29: 2017-2034. doi: 0.1007/s10531-017-1379-8 
Rabello, A. M., Queiroz, A. C., Lasmar, C. J., Cuissi, R. G., Canedo-Júnior, E. O., Schmidt, F. A. \& Ribas, C. R. (2015). When is the best period to sample ants in tropical areas impacted by mining and in rehabilitation process? Insectes Sociaux, 62: 227-236.

Rabello, A.M., Parr, C.L., Queiroz, A.C.M., Braga, D.L., Santiago, G.S. \& Ribas, C.R., (2018). Habitat attribute similarities reduce impacts of land-use conversion on seed removal. Biotropica, 50: 39-49. doi: 10.1111/btp.12506

Raimundo, R.L.G., Guimarães, P. G., Almeida-Neto, M. \& Pizo, M. A. (2004). The influence of fruit morphology and habitat structure on ant-seed interactions: A study with artificial fruits. Sociobiology, 44: 1-10.

Ribeiro, J.F. \& Walter, B.M.T. (1998). Fitofisionomias do bioma Cerrado. In:_Cerrado: ambiente e flora. Embrapa CPAC, Editors: Sueli Matiko Sano, Semíramis Pedrosa de Almeida, 85-16 p.

R Development Core Team 2015. A language and environment for statistical computing. $\mathrm{R}$ Foundation for Statistical Computing, Vienna, Austria. https:/www.R-project.org/

Rocha-Ortega, M., Bartimachi, A., Neves, J., Bruna E.M. \& Vasconcelos H.L. (2017). Seed removal patterns of pioneer trees in an agricultural landscape. Plant Ecology, 218: 737-748. doi: 10.1007/s11258-017-0725-y
Roeder, K.A., Roder, D. V. \& Kapari, M. (2018). The role of temperature in competition and persistence of an invaded ant assemblage. Ecological Entomology, 43: 774-781. doi: 10.1111/een.12663

Santana, F.D., Cazetta, E. \& Delabie, J.H.C. (2013). Interactions between ants and non-myrmecochorus diaspores in a tropical wet forest in southern Bahia, Brazil. Journal of Tropical Ecology, 29: 71-80. doi: 10.1017/S0266467412000715

Yanoviak, S. \& Kaspari, M. (2000). Community structure and the habitat templet: ants in the tropical forest canopy and litter. Oikos, 89: 259-266.

Zelikova, T.J. \& Breed, M.D. (2008) Effects of habitat disturbance on ant community composition and seed dispersal by ants in a tropical dry forest in Costa Rica. Journal of Tropical Ecology, 24: 309-316. doi: 10.1017/S0266467408004999

Warren II, R.J., Giladi, I \& Bradford, M.A. (2012). Environmental heterogeneity and interspecific interactions influence nest occupancy by key seed-dispersing ants. Environmental Entomology, 41: 463-468. doi: 10.1603/EN12027

Weiser, M.D., Sanders, N.J., Agosti, D., et al. (2010). Canopy and litter ant assemblages share similar climate-species density relationships. Biology Letters, 6: 769-772. doi: 10.1098/rsbl. 2010.0151

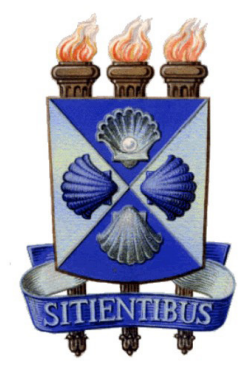

